\title{
Do stranded sand dollars indicate hydrodynamic conditions of sandy beaches?
}

\begin{abstract}
This article aimed to evaluate sand dollars' distribution (Mellitaquinquiesperforata) by relating it to hydrodynamic variations on Santos Beach (Brazil). Twenty-nine samplings were carried out between March 2015 and July 2018, through 6 transects in the seawater limit, along $5.5 \mathrm{~km}$ of the beach. The survey of data consisted of two processes: counting and biometrics of the whole individuals present. We noted the wind's direction, the height of the tide, the lunar phase, and the seasons. Canonical Correspondence Analysis and 2way ANOVAs showed that the season, the direction of the prevailing winds, and the moon phase significantly influenced the cookies' spatial distribution, results that coincide with the existing models for erosion and sedimentation. We only registered adult individuals $(>4 \mathrm{~cm})$. The largest and heaviest individuals occurred in late summer and early autumn (March-April), which suggests that this is the species' breeding season.
\end{abstract}

Keywords: bioindicator, spatial distribution, seasonal and circadian variations
Volume 10 Issue 2 - 202I

\begin{abstract}
Fátima Aparecida Rocha e Silva,' Fernanda Sales Sanches, ${ }^{2}$ Walter Barrella ${ }^{1,2}$

'UNISANTA - Universidade Santa Cecília, Programa de PósGraduação em Sustentabilidade de Ecossistemas Costeiros e Marinhos, Brazil
\end{abstract}

${ }^{2}$ UNIP- Universidade Paulista, Avenida Independência, Brazil

Correspondence: Walter Barrella, UNISANTA - Universidade Santa Cecília, Programa de Pós-Graduação em Sustentabilidade de Ecossistemas Costeiros e Marinhos, Brazil,

Email walterbarrella@gmail.com

Received: April 22, 2021 | Published: May 05, 2021

\section{Introduction}

Considered the broadest of coastal sedimentary ecosystems, the habitat of sandy beaches is marked by high dynamism, directly influenced by abiotic factors such as tidal regimes, wave height, light incidence, wind regime, among others. ${ }^{1}$ The increasing urbanization of these coastal areas causes changes in abrasion and marine deposition cycles, with the potential risk of damage., ${ }^{2,3}$ Coastal defense constructions reduce the problem; however, detailed knowledge of the system's hydrodynamics is necessary to present efficient and less costly solutions.

Mathematical models elaborated to understand the beaches' dynamism, using hydrosphere, atmosphere, and lithosphere variables. Variables in the biosphere, although little used, can also indicate changes at different scales, complementing existing abiotic mathematical models and generating new ones. ${ }^{4}$ Some species could indicate the hydrodynamics of sandy beaches. However, to ensure its usefulness, they need to be selected according to measurability, sensitivity, specificity, and predictability. Besides, it is essential that they are integrative (key species) and used elsewhere. The best biological indicators reflect the dynamic nature of ecosystems and bring their beneficiaries closer together, allowing monitoring and understanding of environmental changes' implications. ${ }^{5}$

Considering the above, we found that sand dollar (Mellita quinquiesperforata) may have the potential of an ecological indicator of sandy beaches' hydrodynamic conditions. The species Mellita quinquiesperforata is noteworthy for its abundance on sandy beaches. An echinoid characterized by a flattened circular disc body, it inhabits the region of the sub-territory of unconsolidated environments with gregarious behavior, ${ }^{6-8}$ acting as a sediment modifying agent, regenerating nutrients and reducing debris and the anaerobic zone, thus influencing the structure of sandy beach benthic communities. ${ }^{9-11}$

We related the distribution of sand dollars stranded on the above coast of Santos Beach (Brazil) with the season, wind direction, moon phases, and tidal height. Our objective was to verify the potential of using sea wafers to indicate erosion and sedimentation processes on sandy beaches.

\section{Study area}

Located in the southeastern portion of the Brazilian coast, Santos Bay has a high demographic density. It has a $12 \mathrm{~km}$ long opening facing SE-S, in a total area of $30 \mathrm{~km}^{2} .{ }^{12}$ Santos Beach stretches for $5.5 \mathrm{~km}$ of a sandy strip with fine-grained, homogeneous sediments and with sub-horizontal slope (inclination $<10^{\circ}$ ), which characterizes it as a dissipative type. ${ }^{13}$ The presence of six drainage channels, whose constructions reach the region between tides, interfere with the beach's hydrodynamic regime (Figure 1).

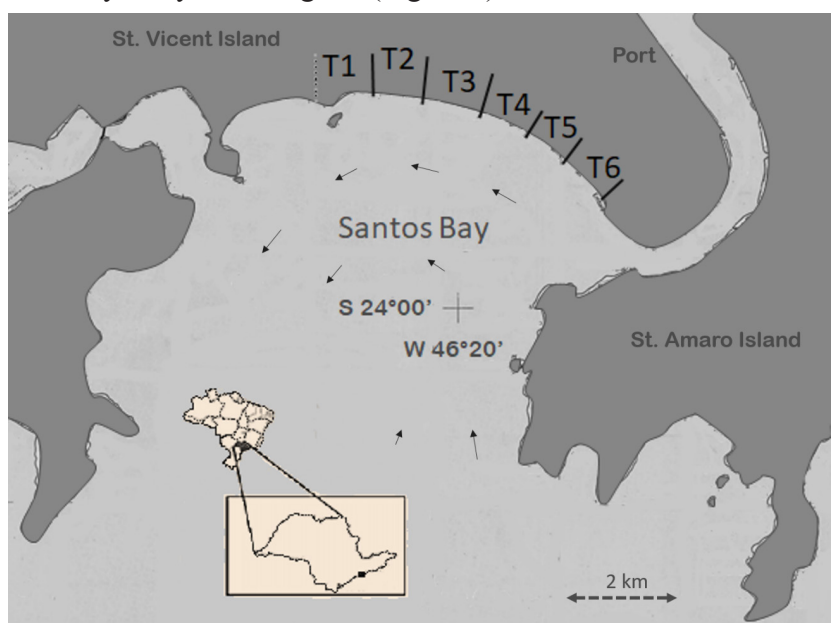

Figure I Location map of the study area. The arrows show the predominant currents in Santos Bay. The transects (TI to T6) were considered for the counting and biometrics of sand dollars that arrived on the superior coast of Santos Beach (Brazil).

\section{Data collection and analysis}

For the analysis of the spatial distribution of sand dollars (Mellita quinquiesperforata), we carried out samplings between March 2015 
and July 2018. Each sampling was carried out along the beach $(5.5 \mathrm{~km})$, a strip of $10 \mathrm{~m}$ width ( 5 meters in water, and 5 meters in the dry), divided into six transects (T1 to T6), limited by the drainage channels (Figure 1). We count all individuals and note the measurements of their width and the weights of the whole and living individuals. With information on the abundances, we used a Cluster Analysis to verify similarities between the studied beach's stretches. We also added information about the season, moon phases, sea level, and wind direction and performed a Canonical Correspondence Analysis (CCA) to relate the environmental and biological characteristics in the sampled transects. We also performed analyzes of variance two-way, with Tukey test a posteriori. We used the natural log of abundances (ln $(\mathrm{x}+1))$ as the response variable to verify differences in the six groups of transects (T - with six levels: T1 to T6); in the four seasons (Swith four levels: spring, summer, autumn, and winter), in the three predominant directions of the wind, (Wind with three levels GE- East winds; GS- South and GW winds - West winds ), in the 4 phases of the moon (new, crescent, full and waning) and two tide levels (low below $0.4 \mathrm{~m}$ and high above this limit). Biometric data were used as response variables in ANOVA two-way to verify differences in the six transects ( $\mathrm{T} 1$ to $\mathrm{T} 6$ ) and relation to the four seasons (spring, summer, autumn, and winter).

\section{Results}

We registered 4881 individuals with an average of $168.3( \pm 117.2)$ individuals per sample. Table 1 presents abiotic information and the numbers of individuals collected from the six transects in the 29 samples, and figure 2 shows the average number of individuals (a), the result of the cluster analysis (b), and the canonical correlation analysis (c).

Table I Abiotic information (date, season, lunar phase, the height of the tide and direction of prevailing winds), and the number of individuals registered per Santos Beach stretch

\begin{tabular}{|c|c|c|c|c|c|c|c|c|c|c|c|}
\hline Date & Season & Moon & LevelSea (m) & $\begin{array}{l}\text { Predominant Wind } \\
\text { Direction }\end{array}$ & TI & $\mathbf{T} 2$ & T3 & T4 & T5 & T6 & Total \\
\hline $05 / 03 / 2015$ & Summer & Full Moon & 0,2 & NNW & 59 & 119 & 28 & 13 & 12 & 0 & 231 \\
\hline $06 / 03 / 2015$ & Summer & Full Moon & 0,2 & NNW & 47 & 99 & 30 & 9 & 12 & 3 & 200 \\
\hline $13 / 03 / 2015$ & Summer & Third Quarter & 0,8 & NNE & 3 & 72 & 106 & 23 & 12 & 1 & 217 \\
\hline $20 / 03 / 2015$ & Autumn & New Moon & 0,2 & SSW & 9 & 150 & 27 & 25 & 135 & 60 & 406 \\
\hline $27 / 03 / 2015$ & Autumn & First Quarter & 0,7 & SSW & 11 & 85 & 44 & 15 & 7 & I & 163 \\
\hline $24 / 04 / 2015$ & Autumn & New Moon & 0,5 & WNW & 0 & 25 & 15 & 7 & 1 & 0 & 48 \\
\hline $14 / 05 / 20 \mid 5$ & Autumn & Third Quarter & 0,4 & ENE & 0 & 4 & 4 & 7 & 2 & I & 18 \\
\hline $16 / 05 / 2015$ & Autumn & New Moon & 0,3 & NNE & 18 & 67 & 79 & 44 & 28 & 0 & 236 \\
\hline $11 / 06 / 2015$ & Autumn & Third Quarter & 0,6 & NNW & 0 & 0 & 3 & 3 & 0 & 2 & 8 \\
\hline $31 / 07 / 2015$ & Winter & Full Moon & $-0,1$ & ESE & 0 & 0 & 17 & 20 & II & 152 & 200 \\
\hline $14 / 08 / 20 \mid 5$ & Winter & New Moon & 0,1 & NNE & 0 & 28 & 28 & 54 & 50 & 15 & 175 \\
\hline $02 / 10 / 2015$ & Spring & Full Moon & 0,5 & ESE & 4 & 0 & 46 & 31 & 68 & 8 & 157 \\
\hline $08 / 10 / 2015$ & Spring & Third Quarter & $\mathrm{I}, 3$ & NNE & 0 & 23 & 53 & 72 & 51 & 6 & 205 \\
\hline $13 / 1 \mid / 2015$ & Spring & New Moon & 0,3 & ESE & 2 & 3 & 5 & 15 & 10 & 2 & 37 \\
\hline $20 / 11 / 2015$ & Spring & First Quarter & $\mathrm{I}, 2$ & NNW & I & 4 & 15 & 3 & 5 & 3 & 31 \\
\hline $27 / 11 / 2015$ & Spring & Full Moon & 0,4 & ESE & 58 & 39 & 37 & 53 & 27 & 4 & 218 \\
\hline $09 / 03 / 2017$ & Summer & Full Moon & 0,5 & $E$ & 27 & 99 & 52 & 79 & 133 & 67 & 457 \\
\hline 09/03/2017 & Summer & Full Moon & $\mathrm{I}, 2$ & $E$ & II & 71 & 46 & 172 & 129 & 34 & 463 \\
\hline $26 / 08 / 2017$ & Winter & New Moon & 0,4 & $S$ & 35 & 4 & 10 & II & 19 & 48 & 127 \\
\hline $23 / 09 / 2017$ & Spring & new moon & 0,3 & W & 14 & 8 & 34 & 11 & 5 & 6 & 78 \\
\hline $21 / 10 / 2017$ & Spring & New Moon & 0,3 & $E$ & II & II & 28 & 47 & 56 & 4 & 157 \\
\hline $25 / 11 / 2017$ & Spring & First Quarter & 0,3 & SE & 3 & 6 & 22 & 4 & 3 & 15 & 53 \\
\hline $30 / 12 / 2017$ & Summer & First Quarter & 0,3 & $E$ & 7 & 4 & 5 & 23 & 15 & 6 & 60 \\
\hline $27 / 01 / 2018$ & Summer & Full Moon & 0,5 & ESE & 0 & 21 & 40 & 28 & 7 & 17 & 113 \\
\hline $25 / 02 / 2018$ & Summer & First Quarter & 0,6 & $E$ & 3 & 19 & 72 & 74 & 30 & 5 & 203 \\
\hline $18 / 03 / 2018$ & Summer & New Moon & 0,3 & $\mathrm{~S}$ & 0 & 12 & 37 & 54 & 89 & 19 & 211 \\
\hline $29 / 04 / 2018$ & Autumn & Full Moon & 0,1 & $E$ & 2 & 20 & 48 & 69 & 63 & 22 & 224 \\
\hline $18 / 07 / 2018$ & Winter & First Quarter & 0,4 & $\mathrm{~S}$ & 4 & 3 & 24 & 15 & 40 & 6 & 92 \\
\hline
\end{tabular}


Table Continued...

\begin{tabular}{|c|c|c|c|c|c|c|c|c|c|c|c|}
\hline Date & Season & Moon & LevelSea (m) & $\begin{array}{l}\text { Predominant Wind } \\
\text { Direction }\end{array}$ & TI & T2 & T3 & T4 & T5 & T6 & Total \\
\hline \multirow[t]{4}{*}{$18 / 07 / 2018$} & Winter & First Quarter & 1 & $S$ & 5 & 2 & I & I & 53 & 31 & 93 \\
\hline & & & & Total & 334 & 998 & 956 & 982 & 1073 & 538 & 4881 \\
\hline & & & & Average & 11,5 & 34,4 & 33,0 & 33,9 & 37,0 & 18,6 & 168,3 \\
\hline & & & & SD & 16,9 & $4 I, I$ & 23,9 & 35,2 & 39,8 & 30,8 & 117,2 \\
\hline
\end{tabular}

Figure 3 shows the results of the two-way analysis of variances and the Tukey tests for factors that showed significant differences and, Table 2 shows the Tukey test results for the sample means. We verified the significant influence of the season, the direction of the prevailing winds, and the moon phases $(\mathrm{p}<0.01)$. The interactions between the variables were not significant. Figure $3 \mathrm{a}$ showed that during the summer, the number was higher in transects T1a T4, while in winter, we registered a higher number of individuals in transect T6. Summer and autumn showed significant differences using the Tukey test. The samples obtained during the East quadrant (GE) winds showed more individuals in transects $\mathrm{T} 2$ and $\mathrm{T} 3$, while in the west $(\mathrm{GW})$ and south (GS) winds, we verified a higher proportion of cookies between transects T5 and T6 (Figure 3b). A highlight for West winds (GW) that showed significant differences. We recorded higher numbers of individuals in the moons of syzygy (New and Full Moon) than the quadrature phases (First and Third quarter of the moon). The full moon results were significantly different from those found on the 1 st and 3rd quarter moons (Figure 3c). Those obtained in the new moon were different only from the 1st quarter. The height of the sea level, on the other hand, had no significant effect on the distribution of individuals along the beach (Figure 3d).
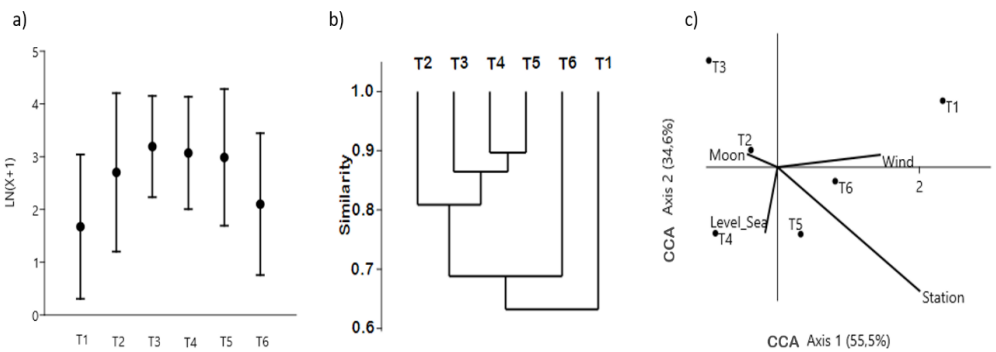

Figure 2 (a) Average number (with standard deviations) of individuals registered in transects TI to T6 at Santos beach; (b) Transect cluster, using a connection by the UPGMA method, and Bray-Curtis similarity $(C C C=0.93)$; (c) Canonical Correspondence Analysis between abiotic and biotic variables of the samples.
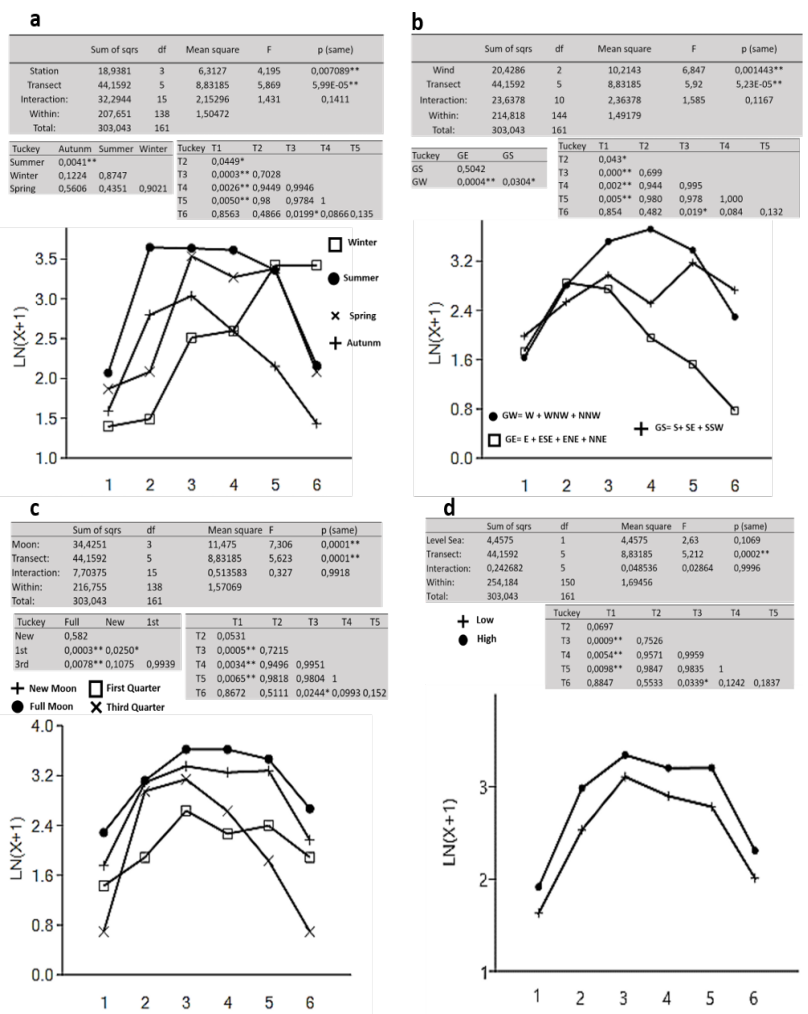

Figure 3 Analysis of variances, Tukey tests and graphs of individual abundances (In $(x+1)$ ) along with transects I to 6 (abscissa) of Praia de Santos: a) seasons; b) groups of predominant winds; c) phases of the moon and; d) sea level.

Citation: Silva FAR, Sanches FS, Barrella W. Do stranded sand dollars indicate hydrodynamic conditions of sandy beaches? J Aquac Mar Biol. 2021;10(2):8I-86. DOI: 10.15406/jamb.2021.10.00310 
Table 2 Tukey test results for the sample mean for the environmental factors studied

\begin{tabular}{lcccccc}
\hline & TI & T2 & T3 & T4 & T5 & T6 \\
\hline Station & a & b & b & b & b & a \\
Wind & a & b & b & b & b & a \\
Moon & a & a & b & b & b & a \\
Sealevel & a & a & b & b & b & a \\
\hline
\end{tabular}

We measured the width and weight of 1192 sand dollars, whose weight-length regression equation (Figure 4). The animals' size ranged from 5.4 to $10.8 \mathrm{~cm}$ in carapace width, while the weight varied from 7, 9 to 59g. Still in Figure 4, in its lower part, it details the results of the analysis of variances and Tukey test with significant differences $(p<0.01)$ of the seasons and the stretches of the beaches (Figure 4 below). The individuals measured in transects $\mathrm{T} 1$ to $\mathrm{T} 4$ were larger and heavier, especially in summer and autumn, while in sections T5 and T6, such differences were less relevant.
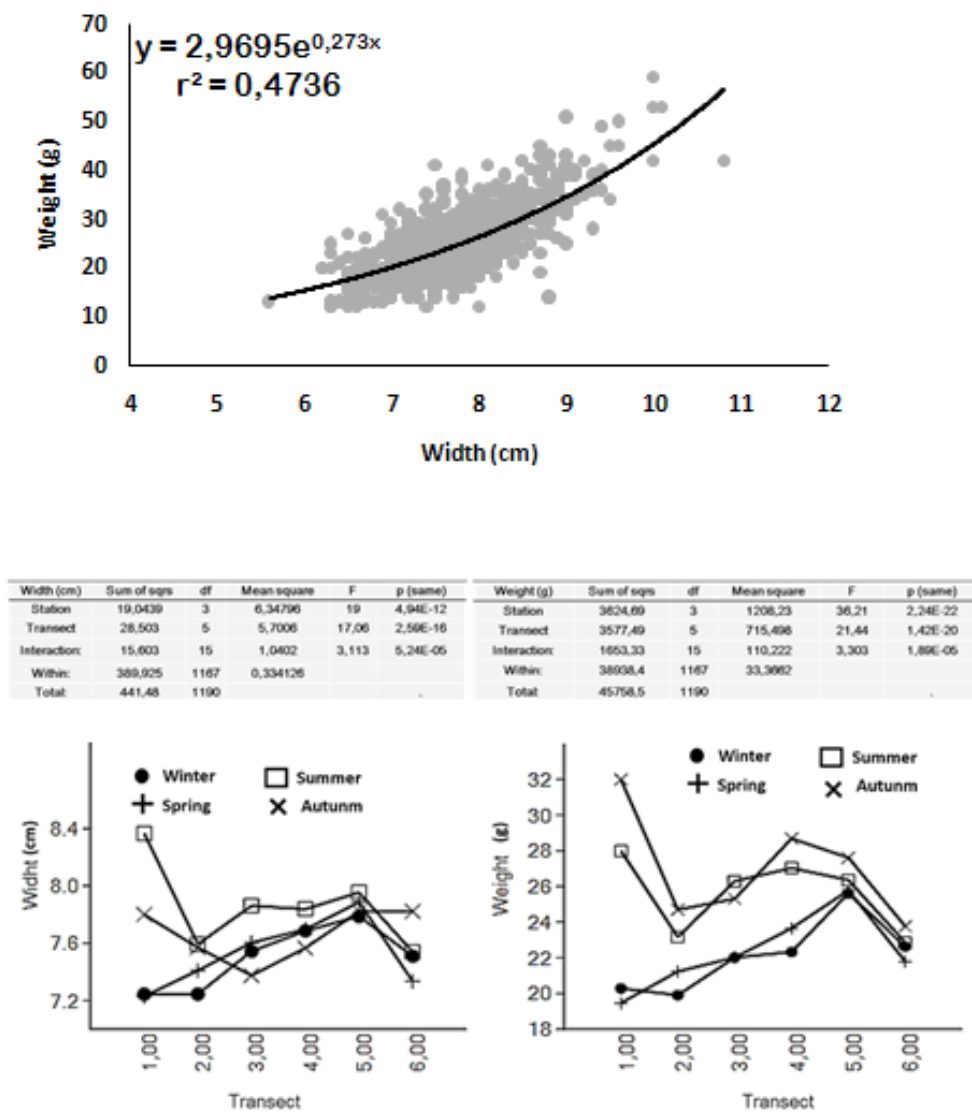

Figure 4 Above: weight-length regression of 1192 living individuals. Bottom left: Two-way ANOVA for the average width of individuals in the transects and seasons. Bottom right:ANOVA two way for average sea biscuit weights on each beach stretch in the seasons.

\section{Discussion}

Santos Bay has studies that assess the impacts of the works on the adjacent beaches. Such studies include modeling of topographic profiles and analysis of the sedimentary balance of the beach related to the flow of the estuary, water renewal, saline intrusion, and propagation of tidal currents. ${ }^{14-22}$ The results point to bathymetric changes and significant changes in the circulation of the estuary. However, they use macro-scales to render the accurate representation of specific stretches of the beach unfeasible. Thus, it is essential to update the information, considering the effects of a small magnitude that any intervention causes in the entire adjacent coastal region. Only then will it be possible to obtain a more detailed understanding of the existing erosive processes. In this regard, information on biological characteristics can serve as a complement to feed the existing models.

The displacement and release of sand dollars to the supralittoral are associated with wave and wind patterns, erosion, transport, and sedimentation processes. The Canonical Correspondence Analysis (Figure 2c) showed that the seasons and the prevailing wind regimes were the most important variables in distributing sea biscuits. In Transecto T1, there was always a lower number of cookies, while in Transecto T6, we found a higher number of individuals only in winter when winds from the South quadrant are frequent (Figure 3a).In the middle stretch of the beach (T3-T5), a higher number of individuals occurred in spring and summer, while in autumn, we found predominance in $\mathrm{T} 2$ and $\mathrm{T} 3$. The direction of the prevailing winds also showed a significant effect $(p=0.001)$ on these organisms' spatial distribution (Figure $3 b$ ) because the beach is sheltered from the East waves, partially from the Southeast waves, and exposed to the South and Southwest waves. Throughout the year, swellings from the East and Southeast predominate; however, with the entry of cold winter fronts, swells from the South and Southwest affect mainly the region of transects $\mathrm{T} 5$ and $\mathrm{T} 6,{ }^{23,24}$ depositing large quantities of cookies in the supralittoral. West winds increase the drag force of sand dollars between the $\mathrm{T} 3$ to $\mathrm{T} 5$ transects because it raises the surf wave increasing its influence and producing good waves for surfing.

The external transects ( $\mathrm{T} 1$ and $\mathrm{T} 6$ ) showed lower amounts of cookies (Figures 2 and b). These transects have different 
hydrodynamic patterns from the rest, as shown by all statistical analyzes (Figure 3 and Table 2). Grounding, the submarine outfall spike blocks the overflow of sediments, making the T1 transect section more prone to sedimentation. ${ }^{25}$ In the Santos Bay circulation and sedimentation model presented by Magini et al., ${ }^{23}$ it was possible to verify sedimentation areas close to the submarine outfall, between transects T1 and T3. On the other hand, longitudinal coastal transport with a negative result in the T6 transect presents a strong tendency to erosion due to the proximity of the Porto de Santos channel. ${ }^{26}$

Transects T4 and T5 showed more similar patterns (Figure 2b), corroborating the results of Carminato et al..$^{27,28}$ The latter found similarities in the deposition of floating garbage along Santos Beach, which results in the frequent east winds that produce waves with moderate erosive action, transporting sediment to the opposite side of the beach (T2-T3), where there is a continuous deposition by longitudinal transport. The Sand dollars' circular shape increases their buoyancy, responding to floating residues' deposition in the supralittoral. However, massive hangovers caused by the entry of cold fronts and S and SO winds intensify erosion near the port-channel and increase the number of cookies launched in the T5 and T6 transects. The sediment removed from this area (T5 and T6) is transported to the other side of the beach (T2 and T3), which suffers frequent silting up by the sea sand, with large amounts of sand released. ${ }^{24} \mathrm{At}$ the end of the winter of 2017, when the erosive processes that occurred in Transect T5 lowered more than $2.0 \mathrm{~m}$ of sand, discovering the wreckage of the "Krestel" sailboat that sank in 1895.

The erosion and sedimentation sites in Santos Bay's surf areas also vary according to the tidal movement. The spring tides (Lua Nova and Cheia) produced significant variations in the number of cookies (Figure 3c), confirming the results of Cordeiro et al. ${ }^{28}$ Despite this, the sea level observed at the sampling time did not show any significant differences related to the number of cookies along the transects (Figure 3d).

The size of the sand dollars was another favorable factor for their use as an indicator of the hydrological dynamics of Praia de Santos. Figure 4 shows a predominance of adult animals, with higher chances of reproducing before being released to the supra coast and dying ${ }^{29-34}$ found that water turbulence induces behavioral responses to the transition of Pacific sand dollar larvae (Dendraster excentricus) from the planktonic to the benthic phase. This same phenomenon may not occur with the larvae of Melitta quinquesperforata, seen by the absence of younger individuals (below $4 \mathrm{~cm}$ ) that possibly occupy places distant from the surf zone of Santos beach. Serafy ${ }^{35}$ describes the population dynamics of Mellita quinquesperforata as too abundant in sandy bottoms, with mass mortality events influenced by abrupt environmental changes or the depletion of food resources. The sediments of Praia de Santos are rich in organic material with continuous input of food resources, together with the low variation in abiotic conditions, produce a favorable habitat for the establishment of a large population of sea biscuits, and its use as an ecological indicator does not it would imply no danger to this population. ${ }^{36,37}$ In the T1 transect, the largest and heaviest individuals were found, mainly in the summer (Figure 4), which suggests their reproductive season. This echinoid arouses interest not only in researchers. ${ }^{38,39}$ Bathers, surfers, and other regulars could also monitor sandy beaches in different parts of the planet in Citizen Science programs. ${ }^{40,42}$

\section{Conclusions}

The distribution of individuals of the species Mellita quinquiesperforata, thrown to the upper coast of Santos' beaches, is influenced by the action of different environmental factors, highlighting the direction of the winds in the different seasons and lunar phases.

The ends of the beach show different patterns of abundance of sand dollars, while in the intermediate stretches, the distributions and abundances were similar and related to the processes of erosion and sedimentation.

The pattern of distribution of individuals of the species Mellita quinquiesperforata, launched to the supreme coast of Santos' beaches, corroborates with the known models of circulation and sedimentation and has the potential to be used as a bioindicator of the abiotic conditions of the surf zone of Santos Bay.

\section{Conflicts of interest}

The author declares that there are no conflicts of interest.

\section{Funding}

None.

\section{Acknowledgments}

None.

\section{References}

1. Davis RA. Beach and nearshore zone. In: Davis RA. Editor. Coastal Sedimentary Environments. New York, Springer-Verlag.1985;379-444.

2. Souza CRG. Praias arenosas oceânicas do estado de São Paulo (Brasil): síntese dos conhecimentos sobre morfodinâmica, sedimentologia, transporte costeiro e erosão costeira. Revista do Departamento de Geografia-USP. Volume Especial 30 Anos. 2012;307-371.

3. Cooper JAG, O Connor MC, McIvor S. Coastal defenses versus coastal ecosystems: A regional appraisal. Marine Policy. 2016.

4. Laurila-Pant M, Lehikoinen A, Uusitalo L, et al. How to value biodiversity in environmental management? Ecological Indicators. 2015;55:1-11.

5. Hattam C, Atkins JP, Beaumont N, et al. Marine ecosystem services: Linking indicators to their classification. Ecological Indicators. 2015;49:61-75.

6. Borzone CA, Tavares YAG, Soares CR. Adaptação morfológica de Mellitaquinquiesperforata (Clypeasteroida, Mellitidae) para explorar ambientes com alto hidrodinamismo. Iheringia, Ser.Zool, Porto Alegre. $1997 ; 82: 33-42$

7. Borzone CA, Tavares YAG. Morphometric variations of Mellitaquinquiesperforata (Leske, 1778) in different sandy beaches environments. In: Echinoderms: San Francisco, R. Mooi e M. Telford (Eds). Proceedings of the 9th International Conference of Echinoderms, Balkema: Rotterdam. 1998. p. 579.

8. Ribeiro-Costa CS, Rocha RM. Invertebrados: manual de aulas práticas. Ribeirão Preto: Holos, 2002.

9. White DC, Findlay RH, Fazio SD. Effects of bioturbation and predation by Mellitaquinquiesperforata on sedimentary microbial community structure. In: Estuarine Perspectives. New York: Academic Press, 1980;163-171.

10. Findlay RH, White DC. The effects of feeding by the sand dollar Mellitaquinquiesperforata (Leske) on the benthic microbial community. J Exp Mar Ecol. 1983;72(1)25-41.

11. Reidenauer JA. Sand dollar Mellitaquinquiesperforata (Leske) burrowtrails, sites of harpaticoid disturbance and nematode attraction. $J$ Exp Mar Ecol. 1989;130(3):223-235.

12. Dhn, diretoria de hidrografia e navegação, Carta Náutica do Porto de Santos. Marinha do Brasil, Departamento de Hidrografia e Navegação. 2003. 
13. Mclachlan A, Erasmus T. Sandy beaches as ecosystems. The Hague, Dr W Junk. 1983; p.757.

14. Sondotecnica. Estudo Diagnóstico do comportamento hidráulico e sedimentológico da baía de Santos - Estuário Santista. São Paulo. 1977.

15. Harari J, Camargo R. Numerical simulation of the tidal propagation in the coastal region of Santos (Brazil, $\left.24^{\circ} \mathrm{S} 46^{\circ} \mathrm{W}\right)$. Continental Shelf Research v. 2003;23(16):1597-1613.

16. INSTITUTO Militar de Engenharia (IME). Modelagem Hidrodinâmica do Porto de Santos. Relatório Final. IME, jan. 2018.

17. Fundação De Estudos E Pesquisas Aquáticas (FUNDESPA). Plano Básico Ambiental da Dragagem de Aprofundamento do Porto de Santos. Santos: Codesp/Fundespa, 2011. $2^{\circ}$ Relatório Técnico Semestral RTS 140611. 2010.

18. Fundação De Estudos E Pesquisas Aquáticas (Fundespa). RDC - 120612 - Estudo sobre a Hidrodinâmica e o Transporte de Sedimentos na Ponta da Praia de Santos e Praia do Góes. Santos: Codesp/Fundespa, 2013a.

19. Correa TB, Souza CMMA, Gireli TZ. The Influence of Tidal Prism on Port of Santos Dredging. In: international conference on coastal and port engineering in developing countries (PIANC COPEDEC), IX, 2016, Rio de Janeiro. Port and Coastal Environmental Issues and Climate Change.

20. Roversi F, Rosman PCC, Harari J. Análise da renovação das águas do Sistema Estuarino de Santos usando modelagem computacional. Revista Ambiente \& Água. Disponível em. 2016a;11;2:566-585.

21. Porto de santos. Autoridade Portuária. Programa de Gestão do Patrimônio Arqueológico, Histórico e Cultural (Etapas Prospecção, Resgate e Monitoramento): Obras de Dragagem e Derrocamento no Porto Organizado de Santos/SP. 2017.

22. Souza CRG, Souza AP, Ferreira RS. Monitoramento Praial antes durante as obras de dragagem do Porto de Santos, São Paulo (Brasil). In: congreso iberoamericano de gestión integrada de áreas litorales, I, 2012 , Espanha. v. 1. Disponível em.

23. Magini C, Harari J, Abessa DDS. Circulação recente de sedimentos costeiros nas praias de Santos durante eventos de tempestades: dados para a gestão de impactos físicos costeiros. Geociências. 2007;26(4):349-355.

24. Baptistelli SC. Análise crítica da utilização de modelagem matemática na avaliação da dispersão de efluentes leves no litoral da Baixada Santista (Estado de São Paulo) (Doctoraldissertation, Universidade de São Paulo). 2008.

25. Tessler MG, Cazzoli Y Goya S, Yoshikawa PS, et al. São Paulo. In: Muche D. Erosão e progradação no litoral brasileiro. Brasília: MMA. 2017.

26. Fundação Centro Tecnológico De Hidráulica (FCTH). Estudo e pesquisa de obras para a otimização morfológica, náutica e logística do canal de acesso do Porto de Santos. São Paulo: Codesp/FCTH, 2017. Relatório Técnico. 2017;01-1157-16.

27. Carminatto AA, Matuck C, Farraboti E, et al. Deposição dos resíduos sólidos em diferentes marés nas praias de Santos- SP, Brasil. UNISANTA Bioscience. 2017:233 - 247.
28. Cordeiro TC, Barrella W, Butturi-Gomes D, et al. A modeling approach for reposition dynamics of litter composition in coastal areas of the city of Santos, Sao Paulo, Brazil. Marine pollution bulletin. 2018;128, 333-339.

29. Weihe S, Gray I. Observations on the Biology of the Sand Dollar Mellitaquinquiesperforata (Leske). Journal of the Elisha Mitchell Scientific Society. 1968;84(2):315-327.

30. Borzone CA. Spatial distribution and growth of Mellitaquinquiesperforata(Leske, 1778) on a sandy beach of southern Brazil. Nerítica, Curitiba. 1992;71-2: 87-100.

31. Nebelsick Jh, Kroh A. The Stormy Path from Life to Death Assemblages: The Formation and Preservation of Mass Accumulations of Fossil Sand Dollars. PALAIOS. 2002;(4):378-393.

32. Tavares YAG, Borzone CA. Reproductive cycle of Mellitaquinquiesperforata (Leske) (Echinodermata, Echinoidea) in two contrasting beach environments. Revista Brasileira de Zoologia. 2006;23(2):580.

33. Hodin J, Ferner MC, Ng G. Sand dollar larvae show within-population variation in their settlement induction by turbulence. The Biological Bulletin. 2018;235(3):152-166.

34. Ferner MC, Hodin $\mathrm{J}, \mathrm{Ng} \mathrm{G}$, et al. Brief exposure to intense turbulence induces a sustained life-history shift in echinoids. Journal of Experimental Biology. 2019;222(4), jeb187351.

35. Serafy KD. Echinoids (Echinodermata: Echinoidea). Memoirs of the Hourglass Cruises Volume V, Part III. Florida Department of Natural Resources, Marine Research Laboratory. St. Petersburg, FL. 1979; 112 p.

36. Harold AS, Telford M. Systematics, phylogeny, and biogeography of the genus Mellita (Echinoidea: Clypeasteroida). Journal of Natural History. 1990;24(4):987-1026.

37. Salsman G, G Tolbert WH. Observations on the sand dollar, Mellita quinquiesperforata. Limnology and Oceanography. 2003;10(1).

38. Grüss A, Perryman HA, Babcock EA, et al. Monitoring programs of the US Gulf of Mexico: inventory, development, and use of a large monitoring database to map fish and invertebrate spatial distributions. Reviews in Fish Biology and Fisheries. 2018;28(4):667-691.

39. Lykkebo Petersen K, Heck N, G Reguero B, et al. Biological and Physical Effects of Brine Discharge from the Carlsbad Desalination Plant and Implications for Future Desalination Plant Constructions. Water 2019;20734441:11(2).

40. Basco DR, Colburn CB. The State of the Region's Beaches (Hampton Roads, Virginia) The Regional Studies Institute Old Dominion University Norfolk, VA 23529. 2006.

41. Anexo 3 RDC - 120612: Análise Histórica dos Registros de Ressacas ocorridos na região da Baía e Estuário de Santos (jul. 2013). Santos: Codesp/Fundespa. 2013 b.

42. Anexo 6 RDC-120612: Avaliação da Estabilidade do Talude do Canal de Navegação e Modelagem Morfodinâmica na Baía de Santos (jul. 2013). Santos: Codesp/Fundespa. 2013c. 